\title{
Same-sex Parenting Practices in Hungary as an Assertion of Intimate Citizenship
}

\author{
Introduction
}

$\mathrm{T}$ he spring of 2016 brought high hopes and then bitter disappointment for a lesbian couple in the university town of Pécs, near the Croatian border. After one of the two women successfully qualified for adoption, she was chosen as the parent-to-be of a cute 3-year-old girl in state care. The child had been spending most of her weekends with them when an administrator at the local child welfare office decided that lesbians were not fit parents and terminated the adoption process. When the case came to light, a demonstration was organized in Budapest in front of the Ministry of Human Resources, with three lesbian mothers making speeches. This was the first time that in Hungary someone spoke publicly, showing her name and face, as a lesbian parent.

Hungarian law severely curtails the possibilities of same-sex couples to become parents, and rainbow families ${ }^{1}$ have been publicly almost invisible until very recently. This does not mean, however, that there were no attempts to subvert or circumvent state discourses and policies in order to assert the right to parenthood. In this paper I explore such discourses and practices in the Hungarian LGBTQ community through the lens of intimate citizenship. I argue that the concept of intimate citizenship needs to be expanded to encompass the variety of ways LGBTQ people attempt to become parents and/or justify their chosen family forms.

\footnotetext{
${ }^{1}$ Rainbow families are defined as "families with children where parents are lesbian, gay, non-heterosexual or transgender people" (Kuosmanen \& Jämsä 2007, 13, my translation). I will use this term when referring to families composed of same-sex couples with children. Other terms are problematic (Stacey 1996, 107), especially as most of them automatically define the members of the same-sex couple as gay or lesbian, even though this might conflict with their self-definition.
} 
The paper is based on ethnographic fieldwork that I conducted in the Hungarian LGBTQ community² from 2007 to 2013 . I interviewed 68 people who live or have lived in same-sex relationships; 21 of these had children. I conducted participant observation at various workshops, roundtable discussions and other events focusing on family and parenthood, and conducted informal conversations with members of the LGBTQ community. I also examined written sources: an interview volume with lesbian and gay parents published by Inter Alia Association (Sándor 2010), various forum threads on the websites labrisz.hu and pride.hu, and blogs of self-identified gay, lesbian and genderqueer bloggers. Due to the sensitivity of the topic, especially in the Hungarian homophobic context, I protect the anonymity of my respondents by assigning pseudonyms for them, omitting or changing identification data and, in the case of online sources, not publishing the exact online location (which, in the case of pride.hu, is no longer available anyway).

In this paper, I will first discuss the concept of intimate citizenship, and the benefits of applying it to same-sex parenting. I will then outline the legal framework in Hungary and what forms of same-sex parenthood it permits or hinders. Then I will bring examples to how members of the LGBTQ community try to have children in spite of these restrictions, or to justify their ability to parent. Examined through the lens of intimate citizenship, some of these examples can open up new possibilities in theorizing the connection of the individual and the state.

While the sexual/intimate citizenship of LGBTQ people is frequently discussed in American scholarship (e.g. Bell \& Binnie 2000; Canaday 2009; Cossman 2007), these works rarely direct attention to parenthood. One possible reason is that in Anglo-Saxon countries same-sex parenting is less problematic legally and in terms of public attitudes than same-sex marriage, whereas in continental Europe this is the other way round (Takács \& Szalma $2013,2-3)$. It should come as no surprise that much of the not-too-large scholarship examining parenting as a citizenship issue comes from this region (e.g. Ryan-Flood 2009). With this article I hope to add to this thread of citizenship literature and call attention to a hitherto undertheorized field of intimate citizenship.

\section{The intimate citizenship framework}

The notion of intimate citizenship was introduced by Ken Plummer in his work with the same title (Plummer 2003). Under this term he means the possibility of various decisions, access and choices related to the body and intimacy (Plummer 2003, 14). Based but also expanding on this, Roseneil

\footnotetext{
2 The acronym LGBTQ stands for 'Lesbian, Gay, Bisexual, Transgender and Queer'. It is common to also add the letters I (for intersex) and A (for asexual), but during my fieldwork these two groups were barely visible in Hungary, so I felt including their letter would be an empty gesture. While I did not specifically research transgender subjects, they did participate in the workshops and online discussions that I studied.
} 
defines intimate citizenship as "the freedom and ability to construct and live selfhood and a wide range of close relationships - sexual/love relationships, friendships, parental and kin relations - safely, securely and according to personal choice, in their dynamic and changing forms, with respect, recognition and support from state and civil society" (Roseneil \& Stoilova 2011 , 168). We can see that, in contrast to the more often used but also more controversial notion of sexual citizenship (Bell \& Binnie 2000; Phelan 2001; Weeks 1999), intimate citizenship is a broader concept, including also non-sexual intimate relations such as those between parents and children. Also, Roseneil's definition does not limit the scope of this concept to the relationship between the individual and the state, but also includes civil society, that is, other communities of belonging. As we will see, in the struggle to have their parenting rights acknowledged, Hungarian LGBTQ people do not always target the state, but sometimes try to change attitudes in their immediate environment.

Studies on the intimate or sexual citizenship of LGBTQ people often limit themselves to discussing the constraints this group faces within heteronormative mainstream society (Bell and Binnie 2000; Cossman 2007). Other authors recognize the agency of LGBTQ people in claiming recognition for their relationship forms but vary in what they consider the methods for this. Studies on LGBTQ movements tend to focus on activist strategies to lobby for recognition, sometimes explicitly using citizenship rhetoric (Nicolae 2009) or emphasizing their belonging to the nation (Renkin 2009). The agency to argue for social inclusion is not limited to groups or movements, however; much can be done on the individual level. Tereskinas (2008), for instance, argues that in a heteronormative context public coming out can qualify as an assertion of intimate citizenship. Canaday (2009) discusses the way non-heterosexual immigrants to the US found loopholes in the system at a time when state policies would have turned them away. This is similar to de Certeau's notion of tactics, ways to work against the system from inside with rhetoric and everyday practices (de Certeau 1988, 23-24). Some of these practices may be illegal or unrecognized by the law (de Certeau 1988, 25), like the same-sex wedding ceremonies Lewin studied in the US when none of the states officially recognized marriage equality (Lewin 1998).

These ways of claiming intimate citizenship - coming out, alternative discourses, activism, finding loopholes in the system orlegally unacknowledged practices - are observable in the Hungarian LGBTQ community with respect to parenting rights. There are others, too, which are rarely seen as assertions of intimate citizenship, such as language use or 'acting out'. Some of these practices are certainly controversial, but they are useful for highlighting some theoretical difficulties concerning the notion of intimate citizenship. We must also consider that in certain legal and/or social environments not all these solutions are feasible or even possible. Hungarian law is varied with regard to the different forms of rainbow families, so fighting for intimate citizenship requires flexibility in, and often a combination of, the techniques discussed above. 


\section{Rainbow families in Hungary: legal and societal context}

In Hungary the main legal disadvantage same-sex couples face in comparison to heterosexuals is access to parenthood. Individual gays and lesbians can adopt, but not a same-sex couple together ${ }^{3}$. Similarly, single women (regardless of sexual orientation) have access to assisted reproduction techniques (ART), but they have to sign a paper declaring they are single ${ }^{4}$; as cohabitation (whether registered or not) is a different family status, a lesbian living with her partner would commit forgery by signing this document. Hiring a surrogate is punishable by imprisonment of up to 3 years, and so is the practice - popular among lesbians in some countries (Ryan-Flood 2009, 43-76) - of conducting home insemination with a known donor's sperm (in Hungarian law it classifies as "forbidden use of the human body"). As secondparent adoption is also denied to same-sex couples, the biological or adoptive parent's partner cannot gain formal parental status; at best s/he qualifies as a stepparent, which grants certain rights but not equal parenthood. The law explicitly bans same-sex couples from becoming foster parents.

In spite of such difficulties, there is a considerable number of rainbow families in Hungary: in an online LGBQ survey conducted in 2016-2017 $(n=1249), 13 \%$ of respondents were parents; though the majority of children came from heterosexual relationships, 36\% of these families were planned rainbow families (Háttér Társaság 2017, 7). This need not come as a surprise, if we consider that most of the laws mentioned above do not spell out "LGBTQ", they only refer to same-sex couples; individual LGBTQ people qualify for artificial insemination or adoption if they do not have a same-sex partner (or deny having one). The state is apparently less interested in the sexual orientation of single parents than in making sure there are no families with two parents of the same gender so as to preserve the heteronormative model of the family. This results in the "anomaly" that there is a considerable number of families in the country with same-gender parents, but these are not visible in any formal way. No wonder then that one of the main goals of activist organizations working in this field is second-parent adoption.

\section{Activism}

The activities of LGBTQ organizations are perhaps the most widely researched segment of the LGBTQ community. It is understandable: these organizations are easily accessible for research, and scholars not wishing to

\footnotetext{
${ }^{3}$ In the fall of 2020, the Hungarian Parliament passed a law which bans adoption by single persons, except with a special ministry permit. This practically makes it impossible for non-heterosexuals to adopt a child. A protest campaign, under the hashtag \#acsaládazcsalád (\#familyisfamily) has been launched by experts and rainbow families, which was also the first instance adoptive gay male parents have come out in public.
}

${ }^{4}$ Apparently, this rule is not always taken seriously, as some lesbian mothers and mothersto-be I spoke to do not recall ever signing such a document. 
do interviews or participant observation can still get results by looking at the publicly available documents of such groups. Especially groups lobbying for legal change are highly visible in the public sphere, and some scholars put them in the focus of exploring claims for intimate citizenship (Nicolae 2009; Renkin 2009). At the same time, some queer authors criticize these organizations for seeking assimilationist goals and equating legal gains with full citizenship (Bell \& Binnie 2000, 49-50). Such criticism fails to see that many LGBTQ organizations (also ones doing lobbying work) pursue other goals as well like educational programs, consciousness-raising or practical and psychological support within the community (Bruce 2016, 6-7). ${ }^{5}$

The three organizations working for rainbow families in Hungary are a good illustration for this claim. Háttér Society, an NGO with a wide range of programs from community building to mental health, operates a Legal Aid service that also lobbies for second-parent adoption in rainbow families and access to ART for lesbians; but from time to time they organize workshops for members of the LGBTQ community to raise awareness to their rights. Inter Alia Foundation (in operation from 2010 to 2012), besides lobbying for second-parent adoption, published an interview volume with parenting same-sex couples (Sándor 2010), which gave visibility to this extremely closeted group (see next section). The couples describe the way they managed to get a child, which in many cases involved breaking the law. Along the same lines, the Foundation for Rainbow Families used to ${ }^{6}$ organize workshops that gave ideas to participants about how to become parents and manage the challenges of same-sex parenthood. Thus, even activist organizations use several strategies to promote the intimate citizenship of their contingency, even if for casual observers their lobbying activity is the most visible.

Nor are references to the law limited to activists. In fact, the antidiscrimination law, which bans various forms of discrimination on the basis of (among others) sexual orientation and gender identity, can be a powerful tool to claim equal citizenship symbolically and in practical situations. Tekla, a rural working-class mother, fell out with her ex-husband's family because they disapproved of her lesbian relationship and sent the Child Protection Agency to take her kids away, claiming she was leading an 'immoral life'. Fortunately, Tekla had been involved in the local LGBTQ group and had attended a legal awareness training, so she knew that custody cannot be withdrawn on the basis of one's sexual orientation alone. She contacted a lawyer and Háttér Legal Aid, and within two weeks she got her children back (Tekla, interview). Her example shows that claiming equal citizenship with

\footnotetext{
${ }^{5}$ A recent Hungarian example for this partial view is Mészáros (2018), who looks at the word cloud on Háttér Society's website, and as he associates 9 out of the 30 expressions with legal rights, reaches the conclusion that this is the organization's main profile (Mészáros 2018,222 ) - instead of clicking on the general description of the organization, from which he could find out that only one of its seven (?) programs focuses on legal equality.

${ }^{6}$ Since two of its three founders moved abroad a couple of years ago, the activities of the Foundation have been mostly limited to their website.
} 
reference to laws is not limited to organizations but indeed forms part of the repertoire of members of the LGBTQ community in Hungary.

\section{Visibility}

Early gay and lesbian activism in the 1970s promoted coming out as a central tool for achieving equality (Weeks 1985, 197). The power of disclosing one's sexual orientation has been discussed by various authors on the level of individual psychology (Sandford 2000, 23-24), transforming discourses (Plummer 1997, 133-148) and as a prerequisite of collective action (Plummer 1997, 145). Within the postsocialist context, Tereskinas argues that coming out disrupts the invisibility of same-sex sexualities in the public sphere (Tereskinas 2008, 93), something Kuhar calls 'heteronormative panopticon' (Kuhar 2011, 151-152). Others, however, argue against the uncritical adoption of Western notions of visibility in a culturally different region. Stella's Russian respondents see empowerment not in coming out, but in being able to manage their visibility themselves; they experience the closet not as a constraint but as a space where they can get privacy (Stella 2015, 108). The possible dangers that coming out creates do not remain on the individual level; Edenborg demonstrates how in Russia the increased visibility of LGBTQ people has made them suitable scapegoats for the authoritarian state (Edenborg 2017, 76-99).

Hungarian same-sex couples raising children are in a deadlock with respect to visibility. On the one hand, they cannot claim rights or recognition in a context where their very existence is unacknowledged. Though Hungarian media sometimes reports about Western research findings on the ability of gays and lesbians to parent, apart from a few tabloid articles about (invariably female-headed) reconstructed rainbow families, the general public has no awareness that same-sex couples are actually raising children (some of them in planned rainbow families) in contemporary Hungary (Borgos 2011, 89) ${ }^{7}$. If legislators are not aware of the existence of a group, they will not consider granting them rights; similarly, the only way both members of a couple can be acknowledged as their child's parents is if they disclose their relationship to their environment. On the other hand, this is exactly what parents in rainbow families are afraid to do, fearing this would lead to repercussions for their child in various contexts, such as at school (Béres-Deák 2012, 500-503). This is why publications like the Inter Alia interview volume (Sándor 2010) are so important: as the interviews are anonymized, they do not expose rainbow families to backlash, but at the same time raise awareness to their existence and difficulties.

At the same time there are many same-sex parents who come out in their broader environment to claim equality, like Tekla did when she went with her lawyers to the Child Protection Agency. The lesbian mothers at the 2016

${ }^{7}$ On the invisibility of rainbow families in education, see Béres-Deák (2012). 
protest spoke about their experiences in order to pinpoint the difficulties they face in a culture that does not acknowledge same-sex relationships as family; for instance, the last speaker, a social parent, ${ }^{8}$ complained that neither the law nor various institutions recognize her as an equal parent to the child her partner had given birth to (author's field notes). This demonstration potentially signals a new stage in the activism for rainbow families, using the disclosure of personal experience as a tool for creating empathy and for claiming intimate citizenship (Plummer 1997).

\section{Loopholes/ tactics/lies}

As discussed above, Hungarian law severely curtails the rights of lesbians to assisted reproduction techniques. Still, this is the preferred way for women in the LGBTQ community to have children, potentially because there are various opportunities to get around legal barriers. For one thing, the law does not discriminate against non-heterosexual single women; therefore many lesbian couples do not register their partnership, which is then not traceable in legal documents and this makes them potentially eligible for ART. ${ }^{9}$ Even at the time when ART was only accessible to (married or unmarried) heterosexual couples, lesbians found a way to benefit from this service, as Judit's account proves:

When I first went, you couldn't get it as a single woman. And we had no idea it'd change soon, so then there was a pretend father. We said he was the father but his sperm wasn't good so we wanted ART. [...] And when I saw in the newspaper that the law had been adopted and now single women can get it too, I told the doctor there was no father anymore, we'd broken up, but I still wanted the child, even as a single woman (Judit, interview).

This story is an illustration of how flexibly members of the LGBTQ community adapt to the legal framework and its changes. The following story relates such an adaptation with regard to another issue: the fact that (except for anonymous donor insemination) the child's father must be named in official documents. This creates difficulties for women like Zsófi, who did not wish to involve her (known) sperm donor in the child's life or give him any paternal rights, and therefore lied about his marital status.

I couldn't tell the truth. I could have pretended we'd broken up [with the father], but they'd still have pressured me to tell the father's name and make him pay child support. And I didn't want that. So I had to tell a story that would make them let him be and accept the situation as it is. So I had to say he was married (Zsófi, interview).

In this case it is not laws but institutional policies, based on a notion of a direct correspondence of biology and kinship, that caused difficulties

\footnotetext{
${ }^{8}$ I use the term 'social parent' to denote the legal (i.e., biological or adoptive) parent's samesex partner.

${ }^{9}$ As mentioned above, women who simply co-habit with their partner are not officially single either, but their relationship status is harder to prove or disprove.
} 
for Zsófi. The path she chose is controversial in several respects. On the one hand, she felt she was treated with contempt: "I'm a dirty slut because I've lain with a married man" (Zsófi, interview). As Kipnis argues, adultery is also considered a form of 'bad citizenship' (Kipnis 2000,14), so in this sense Zsófi's claim for recognition was unsuccessful, though not on the grounds of her sexual orientation. Also, she did not come out as a lesbian mother; given that her chosen model (two mothers, a child and an uninvolved donor) is not recognized in Hungarian law or mainstream discourses, the best she could do was ensure that the donor is not considered part of her family. Her story is an example of the trade-ins rainbow families are forced to make when legal recognition can only be realized at the cost of invisibility or social marginalization.

In the stories above, women hid their sexual orientation in order to gain access to parenting in a given family form; their sexual citizenship tactics targeted the law and institutional policies. For others, recognition in the public sphere may require other types of lies and silences. Péter and Jocó, a rural gay couple, do not tell strangers which of them is the biological father of their children. "They ask whose child it is. And then we say it belongs to both of $u s^{\prime \prime}$ (Péter, workshop discussion). They are keenly aware that the recognition of kinship in our culture is predicated on biology (Schneider 1968, 23), and they wish to be treated as equal parents to their children. They are also making a public statement, introducing a new conception of family into public discourses; thus, their tactic works on the individual and general level, and on the level of practices as well as discourses. While many LGBTQ people use their personal examples to effect change in their treatment, they often do it with the explicit aim of influencing public discourses as well.

\section{Alternative discourses}

Several authors see rainbow families as a subversion of heteronormative conceptions of kinship (Hayden 2004; Sullivan 2004) and as "the frontrunners of a new form of $21^{\text {st }}$-century family" (Du Chesne and Bradley 2007, 25). For others, parenting is an assimilationist goal that even in its more radical forms reinforces heteronormativity (Bell \& Binnie 2000, 137-138). Lewin, however, warns that a dichotomized view of accommodation and subversion is problematic, as the two are often interconnected (Lewin 1998, 242). A rainbow family is by definition subversive in a context like Hungary, where the law and mainstream discourses see heterosexual relationships as the foundation of kinship. At the same time, LGBTQ people do adhere to certain dominant notions of family while problematizing or rejecting others.

As we have seen, lesbians like Judit and Zsófi do not find it important to involve the child's genitor in their family, whether they used a known or anonymous donor for insemination. This decision runs contrary to the idea that children need parents of both sexes for healthy development, something that is widely propagated in Hungarian popular and scientific discourses (Lux 
2008, 166-167). On the Inter Alia blog, Bea Sándor, founder of the association, counters this notion by exposing its underlying sexism: „[w] hat do you mean by 'male role model'? [...] Not paid work or appearing in public space, surely? Because these are things women can now do too" (Sándor 2010). Far from being assimilationist, this argument attacks the foundations of the heteronormative family model and seeks to substitute it with one that sees gender roles as cultural constructs, supporting Sullivan's claim that lesbian-headed families can be agents of social change towards the deconstruction of gender (Sullivan 2004, 11). Inter Alia Foundation also lobbied strongly for second-parent adoption, and its interview volume (Sándor 2010) propagates two-parent lesbian families without the involvement of any adult men. Besides the gender aspect, this model also disrupts what Schneider calls one of the basic tenets of Western kinship, 'blood is thicker than water' (Schneider 1968, 23), as it claims that the genitor's biogenetic connection does not automatically makes him kin.

While many lesbians in Hungary question the gender-based notion of parenting, others and most gay men I spoke to challenge the mainstream image of the family from another direction: their preferred family model is a gay couple co-parenting with a single woman or a lesbian couple. At a workshop organized by the Foundation for Rainbow Families, a group of participants collected the advantages of this family model: their list included more love, more grandparents who can be mobilized when needed, more role models and more financial resources (author's field notes). These are all values that are often voiced in mainstream Hungarian discourses as foundational for the family. By promoting a three- or four-parent family model, LGBTQ people make use of dominant notions of the family to argue that same-sex parenting in fact serves the interest of the child better than the two-parent heterosexual nuclear family.

Subversive meanings are most successfully communicated if they rely on tropes well-known from dominant narratives (Edenborg 2017, 176-179). Notions of the ideal family within the Hungarian LGBTQ community reinforce some of the values circulating in mainstream discourses but use them to demonstrate the value of rainbow families. Another tactic to assert this value is through the use of language.

\section{Language}

In studies of kinship, the vocabulary used for describing family members has been central for over a century. Early anthropologists debated over the direct correspondence between kinship terms and the corresponding feelings or duties (Parkin 2004). This question resurfaced with postmodernism when, relying on the performativity theory of J. L. Austin (Austin 1962), Marshall Sahlins argued that the use of kin terms performatively creates kinship (Sahlins 2013). The symbolic value of the words used especially for parents is well illustrated by the confusion many people feel at the idea of certain 
assisted reproduction techniques, whereby more than one person could claim the term 'mother' (Edwards 2000).

The idea that there may be two mothers in a lesbian-headed family challenges both the equation of motherhood with giving birth (Hayden 2004,381 ) and the idea that only biogenetically related people should count as parents. Though some female couples reserve the term 'mother' for the woman who gave birth (Polášková 2007, 210-212), others express through their vocabulary that they do not differentiate between biological and social motherhood. Zsófi, whom we met a few pages earlier, separated from her partner a couple of years after our interview and then found a new girlfriend. When we ran into each other at an event, I expressed my joy that her little daughter has two mothers again (testing this way whether her new partner counts as a mother). “Two? She has four, even!”, Zsófi answered, including her ex-partner and her (the ex's) new girlfriend among the child's mothers (author's field notes). Like the workshop participants in the previous section, she is open to extending parenthood to include more than two people, and like Péter and Jocó, considers these parents all equals, worthy of the same recognition.

Due to the performative nature of kin terms (Sahlins 2013), their use can be a path to the recognition of a rainbow family by its environment. Rafael and Gusztáv co-parent two children with a lesbian couple: Rafael is the little girl's, Gusztáv is the little boy's biological father. Biogenetic connection is extremely important for Rafael (indeed this was the reason he opted for coparenting), and he consequentially differentiates between "my daughter" and "his [Gusztáv's] son", correcting the little boy every time he calls him 'daddy' (author's field notes). This approach seemed to backfire with Rafael's father, however, who initially opposed homosexuality and same-sex parenting, and did not like it when his son brought the children to his home, especially the boy, for whom Rafael is the social parent. His attitude improved when the little boy started calling him 'grandpa' (and, perhaps strategically, this time Rafael did not intervene). This story does not only illustrate the power of kinship terms, but also the agency members of rainbow families have in claiming recognition for their family form - already at the age of two.

\section{Illegal practices}

Whereas the practices discussed above are recognized in at least some literature as forms of claiming recognition, to my knowledge no author connects illegal practices with claiming intimate citizenship. After all, citizenship is supposed to mean belonging to a state, so in principle breaking the state's laws would work against it. However, this approach does not consider that membership in a community does not (only) depend on abiding its laws but on living up to its norms. In pronatalist Hungary, childlessness especially among women - is strongly stigmatized (Takács \& Szalma 2014,129 ), proving that in nationalist contexts motherhood is the central 
$\frac{0}{0}$ mechanism for incorporating women in the political order (Pateman 1992, 19). As we have seen, however, the law tries to make sure that women living in lesbian relationships do not have access to reproduction. Thus, in principle same-sex loving women have no access to full citizenship in Hungary.

Recognizing this double bind, many members of the Hungarian LGBTQ community decide that breaking the law in order to achieve parenthood is not a condemnable act. "Those who are not granted the basic human rights (in this case, to give birth to a child and raise her or him in a loving environment with our partner or alone) will look for the 'back door'”, Princess explains on the pride.hu forum. Besides theoretical support, members of the community also help each other with ideas how to circumvent legal barriers. It is common advice, for instance, that women should use home insemination with the sperm of a man they trust, as in this case it is almost impossible to prove they have broken the law. At the parenting workshop focusing on surrogacy, it was mentioned that in order to circumvent the law, some Hungarians used Ukrainian surrogates to make the offence harder to trace (author's fieldnotes).

The latter case is interesting not only because it acknowledges the existence of illegal practices but also because it contests the ethnicity-based definition of the nation dominant in Central and Eastern Europe (Smith 1991, 11). With the example of Israel (another country with strong ethnic nationalism) Hovav demonstrates that such definitions also affect surrogacy, with a preference for surrogates who belong to the 'nation' (Hovav 2011, 1317). The message of the workshop participants is that, in order to gain full symbolic belonging to the nation as parents, gay men must give up, at least partly, the genetically-based conceptions of kinship and nation; a foreign element is necessary to make them full citizens in Hungary. Others emphasize the foreign element even more by saying that they must leave the country in order to gain full equality with heterosexual parents.

\section{Acting out}

$B$ : That's why we want to move to Denmark as soon as possible, because there's marriage and we know several people who are already citizens there and [inaudible].

$K$ : That's definitely my aim, so looking ahead about 10 years, 10 years from now we'd like to be managing the adoption papers already. (...)

$B D R$ : And if in Hungary you had the same possibilities, like you could adopt a child here, would you still want to leave?

$K$ : Probably not.

$B D R$ : So this is in fact what motivates you.

$K$ : That we should be able to live as a family (Bálint and Krisztián, interview).

In the Hungarian LGBTQ community, moving to the West has been a popular strategy from the 1980s onward to escape homophobic climate: in an interview-based research with gay men in 1983, 60\% wanted to leave the country (Takács 2008, 182) and this tendency increased with the opening up of Hungary's borders towards the EU. Bálint and Krisztián are part of a 
more recent trend, whereby same-sex couples leave the country in order to become parents. In the case of adoption this means also giving up their Hungarian citizenship. ${ }^{10}$ Thus formal political citizenship and full intimate citizenship may be mutually exclusive, an issue that citizenship literature has hardly tackled to date. At the same time, when celebrities choose this path like Kristóf Steiner, a popular TV host and author of vegan cookbooks, who moved to Israel with his partner to escape homophobia in Hungary and adopt a child - the general public becomes more aware of the barriers to inclusion same-sex couples face in contemporary Hungary, so the 'acting out' may in fact influence public discourses.

Besides the legal difficulties of becoming parents, many same-sex couples are worried about the homophobic cultural climate in Hungary, which they are afraid may cause difficulties for children growing up in rainbow families. At the same time, plans to move abroad does not necessarily mean lack of attachment to one's home country. Benő, a young gay man who is in the planning phase of parenthood, voices the dilemmas coming from a sense of belonging and distancing at the same time.

\begin{abstract}
$B$ : I don't necessarily plan to raise my children in Hungary.
BDR: You mean [you want to raise them] abroad?

$B$ : Uh-huh. I'm not sure that it'd be good for a child to grow up in present-day Hungarian reality.

$B D R$ : Because his/her ${ }^{11}$ parents are gay, or for other reasons?

$B$ : Er, primarily because his/her parents are gay. But of course, there are other factors, I don't know, I don't really like living in Hungary right now. And that's why. What's strange - not strange but controversial is that I'd really like my child or my children to spend their childhood and part of it in Hungary. So to pass on to them some of this cultural heritage. To learn the language. So it wouldn't only depend on me, or me and my partner that the kids speak good Hungarian, but so they'd spend some time in this environment. So to form in them some of this identity too (Benő, interview).
\end{abstract}

Benő feels an attachment to his home country, which he hopes to pass on to his child, but at the same time, wishes to protect her/him from Hungarian homophobia, a dilemma many members of the Hungarian LGBTQ community face. Imre $(2008,269)$ argues that whereas Hungarian lesbians distance themselves from state-propagated nationalism, they nevertheless appropriate elements of national culture. Though in some cases such moves may be part of a conscious strategy to claim inclusion in the nation (Renkin 2009), Benő feels genuinely attached to his home environment and language. His painful monologue illustrates that the often-celebrated queer internationalism (Altman 2001) may be a necessity rather than free choice for those who are excluded from citizenship in their home country.

\footnotetext{
${ }^{10}$ Not necessarily in the case of ART for lesbians, as in many countries this is accessible for foreign citizens as well; however, the Hungarian state still would not grant full rights to the social parent.

${ }^{11}$ Hungarian does not have grammatical gender, so I translated the third person singular personal pronoun (ó) as s/he.
} 


\section{Conclusion}

Though some authors from Central and Eastern Europe have embraced the concept (see Kuhar 2011; Rédai 2015; Tereskinas 2008), intimate/sexual citizenship has remained largely connected with Western Europe and North America. This has affected the way it is theorized: sexual/intimate citizenship scholars focus largely on activism and public discourses (Bell \& Binnie 2000; Phelan 2001) or inclusion through consumption (Evans 1993), while the everyday practices and discourses of average LGBTQ people largely remain unseen (except e.g., Lewin 1998 or Ryan-Flood 2009). The intimate/ sexual citizenship perspective is usually applied to issues figuring strongly in (North American) activism like marriage equality (Bell \& Binnie 2000; Cossman 2007), but not to same-sex parenting, which is considered less of a problem in that context (though works studying the experiences of gay and lesbian parents in their environment like Lewin (2009) or Mallon (2004) suggest otherwise). Rainbow families figure in scholarship in terms of being similar to or different from heterosexual ones (for a summary of such studies see Biblarz \& Stacey 2010) or as revolutionaries transforming the concept of family (Du Chesne \&Bradley 2007; Sullivan 2004); their actual experiences of inclusion and exclusion are not theorized in the framework of intimate citizenship (with again Ryan-Flood 2009 as a counterexample - tellingly, from Europe). I believe it is time to extend intimate citizenship analysis to rainbow families, as this would enrich the scope and content of this research field. I also believe that examining contexts other than Western through this lens would add valuable insights into processes of inclusion and exclusion. Based on the examples above, I will list a few of these here.

First of all, it is important to consider that not only the goals but also the strategies of LGBTQ people fighting for inclusion depend strongly on the social context. Some scholars from this region do question the usefulness of pride marches, for example, in a context where most people are closeted and their main concerns are not human rights but being accepted in their environment (Bilić 2016; Butterfield 2016), but they operate with a narrow interpretation of human rights, which ostensibly does not contain social rights and social inclusion. I do believe that a struggle for visibility and social inclusion does fit the human rights framework, and we have seen above that these are important for Hungarian present and future LGBTQ parents. The tactics they use to achieve these aims, however, must be adapted to the social environment. In a country where public homophobia prevails, especially in education (Béres-Deák 2012), same-sex parents find it risky to come out in public lest their children should suffer as a consequence; anonymous interviews like the ones in the Inter Alia volume may solve this problem. Also, within a state that grants LGBTQ rights only rarely and grudgingly, most people do not believe in the short-term success of lobbying. Aspiring LGBTQ parents take matters in their own hands, and even activist organizations are willing to assist them. This emphasizes the agency individual community members have in claiming 
intimate citizenship, even if it means circumventing the law. As we have seen, this is not necessarily considered problematic; the notion that unnecessarily constraining laws serving those in power and not the interest of the people can be broken is present in Hungarian public discourses in general (Kapitány \& Kapitány 2007, 230-231) and in the LGBTQ community in particular.

This leads us to my second point: a need to expand the notion of intimate citizenship. Contrary to a narrow interpretation of laws facilitating the inclusion or exclusion of LGBTQ people, a community-oriented view of intimate citizenship also considers discourses, everyday practices and inclusion in civil society, something Manalansan calls cultural citizenship (Manalansan 2003, 16). This broader definition of intimate citizenship, in turn, allows us to examine from this perspective strategies which hitherto have been inadequately theorized in scholarship: language use, finding loopholes in the legal system, illegal or semi-legal practices or leaving the country. The last ones are especially interesting because they highlight the way different forms of citizenship may be mutually exclusive. While a good citizen is supposed to respect the law, s/he (especially she) is also expected to produce offspring, but in a same-sex relationship s/he may be unable to do this without breaking the law. For gay couples who move abroad in order to jointly adopt a child, formal Hungarian citizenship excludes the possibility of being regarded as family, that is, their intimate citizenship. Just like Robertson's claim that suicide (at least in the Japanese context) may be a way of claiming citizenship (Robertson 2007, 224), this form of 'acting out' also exposes the controversies of inclusion within the society that the samesex couple is escaping, especially if the case gets high publicity. At the same time, the stories of gay men forced to leave the country in order to become fathers adds a new perspective to theories of queer transnationalism and globalization.

Hungarian rainbow families have been invisible in both the law and public discourses until recently. They do not passively accept this status, however, but use a wide range of strategies to claim recognition for their family form. Examining these can broaden our understanding of social inclusion and intimate citizenship.

Altman, Denis. 2001. Global Sex. Chicago and London: University of Chicago Press.

Austin, John L. 1962. How to Do Things with Words: The William James Lectures delivered at Harvard University in 1955, ed. by J. O. Urmson, and M. Sbisà. Oxford: Clarendon Press.

Bell, David, and Binnie, Jon. 2000. The Sexual Citizen. Queer Politics and Beyond. Cambridge: Polity Press.

Béres-Deák, Rita. 2012. "Szivárványcsaládok a magyar oktatásban". Új kutatások a neveléstudományokban. A munka és a nevelés világa a tudományban, ed. by K. Tamás and I. Perjés, 491-508. Budapest: MTA Pedagógiai Tudományos Bizottság - ELTE Eötvös Kiadó.

Biblarz, Timothy J., and Stacey, Judith. 2010. "How does the Gender of Parents Matter?". Journal of Marriage and Family 72: 3-22. 
Bilić, Bojan. 2016. "Europe Gays? Europeanisation and Pride Parades in Serbia". LGBT Activism and Europeanisation in the Post-Yugoslav Space. On the Rainbow Way to Europe, ed. by B. Bilić, 117-154. London: Palgrave Macmillan.

Borgos, Anna. 2011. “Diskurzusok a kétanyás családokról: kutatások és közbeszédek”. Homofóbia Magyarországon, ed. by J. Takács, 80-93. Budapest: L’Harmattan.

Bruce, Katherine. 2016. Pride Parades. How a Parade Changed the World. New York: New York University Press.

Butterfield, Nicole. 2016. "Discontents of Professionalisation: Sexual Politics and Activism in Croatia in the Context of EU Accession". LGBT Activism and Europeanisation in the Post-Yugoslav Space. On the Rainbow Way to Europe, ed. by B. Bilić, 23-58. London: Palgrave Macmillan.

Canaday, Margot. 2009. The Straight State. Sexuality and Citizenship in Twentieth-Century America. Princeton and Oxford: Princeton University Press.

Cossman, Brenda. 2007. Sexual Citizens. The Legal and Cultural Regulation of Sex and Belonging. Stanford: Stanford University Press.

De Certeau, Michel. 1988. The Practice of Everyday Life. Berkeley, Los Angeles, London: University of California Press.

Du Chesne, Louise, and Ben Bradley.2007. "The Subjective Experience of the Lesbian (M)other: An Exploration of the Construction of Lesbian Maternal Identity". Gay \& Lesbian Issues and Psychology Review 3 (1): 25-33.

Edenborg, Emil. 2017. Politics of Visibility and Belonging. From Russia's "Homosexual Propaganda" Laws to the Ukraine War. London, New York: Routledge.

Edwards, Jeanette. 2000. Born and Bred. Idioms of Kinship and New Reproductive Technologies in England. Oxford: Oxford University Press.

Evans, David T. 1993. Sexual Citizenship. The Material Construction of Sexualities. London, New York: Routledge.

Háttér Társaság. 2017. Azonos nemü szülők és gyermekeik. Kutatási összefoglaló. Downloaded April 24, 2018. http://hatter.hu/sites/default/files/dokumentum/ kiadvany/szivarvanycsaladok2017.pdf

Hayden, Corinne P. 2004. "Gender, Genetics and Generation: Reformulating Biology in Lesbian Kinship". Kinship and Family. An Anthropological Reader, ed. by R. Parkin, and L. Stone, 378-934. Boston: Blackwell.

Hovav, April. 2011. (Re)conceiving Kinship: Gay Parenthood through Assisted Reproductive Technologies in Israel. MA thesis. Budapest: CEU.

Imre, Anikó. 2008. "Lesbian Nationalism". Signs, 33 (2): 2552-82.

Kapitány, Ágnes, and Gábor Kapitány. 2007. Túlélési stratégiák. Társadalmi adaptációs módok. Budapest: Kossuth Kiadó.

Kipnis, Laura. 2000. "Adultery". Intimacy, ed. by L. Berlant, 9-47. Chicago, London: The University of Chicago Press.

Kuhar, Roman. 2011. "The Heteronormative Panopticon and the Transparent Closet of the Public Space in Slovenia". De-Centring Western Sexualities. Central and Eastern European Perspectives, ed. by R. Kulpa, and J. Mizielińska, 149-166. Farnham, Burlington: Ashgate.

Kuosmanen, Paula, and Jämsä, Juha. 200. Suomalaiset sateenkaariperheet sosiaali- ja terveyspalveluissa ja koulussa. Helsinki: Edita Prima Oy.

Lewin, Ellen. 1998. Recognizing Ourselves. Ceremonies of Lesbian and Gay Commitment. New York: Columbia University Press. 
Lewin, Ellen. 2009. Gay Fatherhood. Narratives of Family and Citizenship in Ameri$c a$. Chicago, London: The University of Chicago Press.

Lux, Elvira. 2008. Női szerepek a szexuálpszichológus szemével. Budapest: Saxum.

Mallon, Gerald P. 2004. Gay Men Choosing Parenthood. New York: Columbia University Press.

Manalansan, Martin F. IV. 2003. Global divas. Filipino gay men in the diaspora. Durham, London: Duke University Press.

Mészáros, György. 2018. “Az LMBT+ identitások és a mozgalom politikai gazdaságtana a félperiférián". Fordulat 24 (2): 215-241.

Nicolae, Lavinia M. 2009. "The marriage between kinship and sexuality in New Mexico's domestic partnership debate". Out in Public. Reinventing Lesbian/Gay Anthropology in a Globalizing World, ed. by E. Lewin, and W. L. Leap, 338-356. Chichester: Wiley-Blackwell.

Parkin, Robert. 2004. "Introduction to Terminology and Affinal Alliance". Kinship and Family. An Anthropological Reader, ed. by R. Parkin, and L. Stone,121-136. Boston: Blackwell.

Pateman, Carole. 1992. "Equality, Difference, subordination: the politics of motherhood and women's citizenship". Beyond Equality and Difference. Citizenship, feminist politics and female subjectivity, ed. by G. Bock, and S. James, 17-32. London, New York: Routledge.

Phelan, Shane. 2001. Sexual Strangers. Gays, Lesbians, and Dilemmas of Citizenship. Philadelphia: Temple University Press.

Plummer, Ken. 1997. Telling Sexual Stories. Power, Change and Social Worlds. London, New York: Routledge.

Plummer, Ken. 2003. Intimate Citizenship. Private Decisions and Public Dialogues. Seattle, London: University of Washington Press.

Polášková, Eva. 2007. "The Czech Lesbian Family Study: Investigating Family Practices". Beyond the Pink Curtain. Everyday Life of LGBT People in Eastern Europe, ed. by R. Kuhar, and J. Takács, 201-216. Ljubljana: Mirovni Inštitut.

Rédai, Dorottya. 2015. Sexing the School: Constituting Gender, Ethnicity and Class Through Discourses of Sexuality in a Hungarian Secondary School. Doctoral dissertation. Budapest: Central European University.

Renkin, Hadley Z. 2009. "Homophobia and Queer Belonging in Hungary". Focaal European Journal of Anthropology 53: 20-37.

Robertson, Jennifer. 2007. "Dying to Tell: Sexuality and Suicide in Imperial Japan". Women's Sexualities and Masculinities in a Globalizing Asia, ed. by S. E. Wieringa, E. Blackwood, and A. Baiya, 217-243. New York: Palgrave Macmillan.

Roseneil, Sasha, and Stoilova, Mariya. 2011. "Heteronormativity, Intimate citizenship and the Regulation of Same-Sex Sexualities in Bulgaria". De-Centring Western Sexualities. Central and Eastern European Perspectives, ed. by R. Kulpa, and J. Mizielińska,167-190. Farnham, Burlington: Ashgate.

Ryan-Flood, Róisín. 2009. Lesbian Motherhood. Gender, Families and Sexual Citizenship. Basingstoke: Palgrave-Macmillan.

Sahlins, Marshall. 2013. What Kinship Is - And Is Not. Chicago and London: University of Chicago Press.

Sandford, Theo. 2000. "Homosexuality, Psychology and Gay and Lesbian Studies". Lesbian and Gay Studies. An Introductory, Interdisciplinary Approach, ed. by T. Sandford, J. Schuyf, J. W. Duyvendak, and J. Weeks, 14-45. London, Thousand Oaks, New Delhi: SAGE. 
@ Sándor, Beáta. 2010. Mi vagyunk a család, a biztonság, az otthona. Leszbikus anyák, meleg apák és 'pótapák'. Budapest: Inter Alia Alapítvány.

Schneider, David. 1968. American Kinship: A cultural account. Englewood Cliffs, New Jersey: Prentice-Hall Inc.

Smith, Anthony D. 1991. National Identity. Reno - Las Vegas: University of Nevada Press.

Stella, Francesca. 2015. Lesbian Lives in Soviet and Post-Soviet Russia. Post/socialism and Gendered Sexualities. Basingstoke, New York: Palgrave Macmillan.

Sullivan, Maureen. 2004. The Family of Woman. Lesbian Mothers, Their Children, and the Undoing of Gender. Berkeley, Los Angeles, London: University of California Press.

Szalma, Ivett, and Takács, Judit. 2014. "Gyermektelenség - és ami mögötte van. Egy interjús vizsgálat eredményei”. Demográfia 57(2-3): 109-136.

Takács, Judit. 2008. Homoszexualitás és társadalom. Budapest: Új Mandátum.

Takács, Judit. 2011. "Homofóbia Magyarországon és Európában”. Homofóbia Magyarországon, ed. by J. Takács, 15-34. Budapest: L'Harmattan.

Takács, Judit, and Szalma, Ivett. 2013. “Az azonos nemű párok általi örökbefogadással kapcsolatos attitűdök Magyarországon”. Socio.hu 7: 1--33.

Tereskinas, Arturas. 2008. "Lithuanian Gays and Lesbians "Coming Out" in the Public/ Private Divide: Sexual Citizenship Lithuanian Style". Gender and Citizenship in a Multicultural Context ed. by P. Oleksy, and B. Waaldijk, 93-108. Frankfurt am Main: Peter Lang.

Weeks, Jeffrey. 1985. Sexuality and Its Discontents. Meanings, Myths and Modern Sexualities. London, New York: Routledge.

Weeks, Jeffrey. 1999. "The Sexual Citizen”. Love and Eroticism, ed. by M. Featherstone, 35-52. London, Thousand Oaks, New Delhi: SAGE. 